\title{
Bariatric surgery and bone metabolism: a systematic review
}

\author{
Cirurgia bariátrica e metabolismo ósseo: uma revisão sistemática
}

Maíra Viégas', Renata Simões de Vasconcelos', Ana Paula Neves' ', Erik Trovão Diniz', Francisco Bandeira'

1 Divisão de Endocrinologia e Diabetes, Hospital Agamenon Magalhães, Sistema Único de Saúde (SUS), Universidade de Pernambuco (UPE). Recife, PE, Brasi
Correspondence to: Francisco Bandeira Av. Rui Barbosa, 1.435 52050-450 - Recife, PE, Brasil fbandeira@gmail.com

Received on Nov/15/2009 Accepted on Feb/19/2010

\section{SUMMARY}

Few studies have demonstrated the risk of metabolic bone disease and a reduction in bone mineral density (BMD) after bariatric surgery. A systematic review was conducted of case-control and cohort studies with the aim of evaluating the relationship between bariatric surgery and bone metabolism. The search was undertaken in MedLine, covering the period from January 1997 to August 2009, using the keywords: "bariatric surgery" AND "osteoporosis", "fracture", "bone diseases", "metabolic". Six studies were included, comprising four cohort and two casecontrol studies. Three studies evaluated bone metabolism and BMD, and the other evaluated bone metabolism only. Based on this review, bariatric surgery is associated with alterations in bone metabolism, loss of bone mass and an increased risk of fracture. However, the maximum evaluation period covered by these studies was two years after surgery, hence the need to undertake further studies of longer duration in order to achieve a more thorough understanding of this association. Arq Bras Endocrinol Metab. 2010;54(2):158-63

\section{Keywords}

Osteoporosis; fracture; bariatric surgery; bone diseases

\section{SUMÁRIO}

Alguns estudos têm demonstrado aumento do risco de doença osteometabólica e redução de densidade mineral óssea (DMO) após a cirurgia bariátrica. Realizou-se uma revisão sistemática de estudos de caso-controle e coorte com o objetivo de avaliar a relação entre cirurgia bariátrica e o metabolismo ósseo. A procura foi realizada na MedLine de janeiro 1997 a agosto 2009, utilizando os descritores: "bariatric surgery" e "osteoporosis", "fracture", "bone diseases", "metabolic". Foram incluídos seis estudos, sendo quatro coortes e dois casos-controle. Três desses estudos avaliaram metabolismo ósseo e DMO e os demais avaliaram apenas o metabolismo ósseo. Com base nesta revisão, a cirurgia bariátrica está associada com alterações no metabolismo ósseo, perda de massa óssea e aumento no risco de fraturas. Entretanto, os estudos tiveram acompanhamento máximo de dois anos após a cirurgia, havendo necessidade de estudos de maior seguimento para melhor conhecimento dessa associação. Arq Bras Endocrinol Metab. 2010;54(2):158-63

\section{Descritores}

Osteoporose; fratura; cirurgia bariátrica; doenças ósseas

\section{INTRODUCTION}

$\mathrm{O}$ besity is a chronic disease in which there is an overstoring of body fat which is defined by body mass index greater than $30 \mathrm{mg} / \mathrm{m}^{2}$. Its prevalence has been steadily increasing to epidemic proportions. According to data from the World Health Organization (WHO), it is estimated that more than 1 billion adults are overweight, around 300 million of whom are cli- nically obese. In the US, in particular, the prevalence of overweight and obese women stands at $72.6 \%$ and $41.8 \%$, respectively (1). Obesity is associated with an increase in overall mortality and a higher risk of developing type 2 diabetes mellitus, dyslipidemia, sleep apnea, gall bladder disease, coronary disease, hypertension, musculoskeletal disorders, cancer and psychosocial disorders (2). 
Vitamin D deficiency has already been well-documented in obese patients (3-9). There is an inverse relationship between serum concentrations of vitamin D (25OHD) and the body mass index (BMI), indicating high levels of parathormone (PTH) $(3-7,10)$.

A cross-sectional study conducted in the US, with 56 men and women, with obesity class II and III demonstrated a decrease in serum 25OHD levels to 1.3 $\mathrm{nmol} / \mathrm{L}$ for each increase of $\mathrm{l} \mathrm{kg} / \mathrm{m}^{2}$ of BMI, and identified the main risk factors for 25OHD insufficiency within this population as being African-American, with a high BMI and little sun exposure (10).

The obesity epidemic, together with the frustrating results of traditional therapies, have led to an increasing number of individuals who are undergoing bariatric surgery, since this has proved the most effective treatment option for reducing weight, improving the quality of life and reducing mortality amongst obese individuals with a BMI $\geq 40 \mathrm{~kg} / \mathrm{m}^{2}$ or $\geq 35 \mathrm{~kg} / \mathrm{m}^{2}$ associated with comorbidities (2).

The most frequent nutritional complications are a deficiency of vitamin B12, folate, zinc, iron, vitamin D and calcium, due to a poor diet, bad digestion and/or poor absorption. The usual types of bariatric surgery are biliopancreatic diversion surgery (Scopinaro), Rouxen-Y gastric bypass surgery (Fobi-Capella), and duodenal switch. In patients submitted to bariatric surgery, a number of studies have demonstrated an increased risk of bone disease and a reduction in bone mineral density (BMD) $(2,11)$. Innumerable factors contribute to BMD reduction after bariatric surgery, such as high levels of PTH resulting from an inadequate intake of calcium and the poor absorption of calcium and vitamin D (12), a fall in biomechanical stress with a loss of weight (13), a decrease in estrogen levels in women (13), a diminution in plasma leptin and ghrelin levels and an increase in plasma adiponectin concentration (2). The aim of this study is to undertake a systematic review of case-control and cohort studies in order to evaluate the relationship between bariatric surgery and bone metabolism.

\section{METHODS}

\section{Study selection}

\section{Strategy for searching the literature}

The search was undertaken in the MedLine database covering the period from January 1997 to August 2009, using the keywords: "bariatric surgery" AND "osteoporosis", "fracture", "bone diseases", "metabolic". Only English language studies involving human adults were selected.

\section{Inclusion criteria}

Case-control and cohort studies in English were selected, consisting of individuals aged 18 years or more (Figure 1).

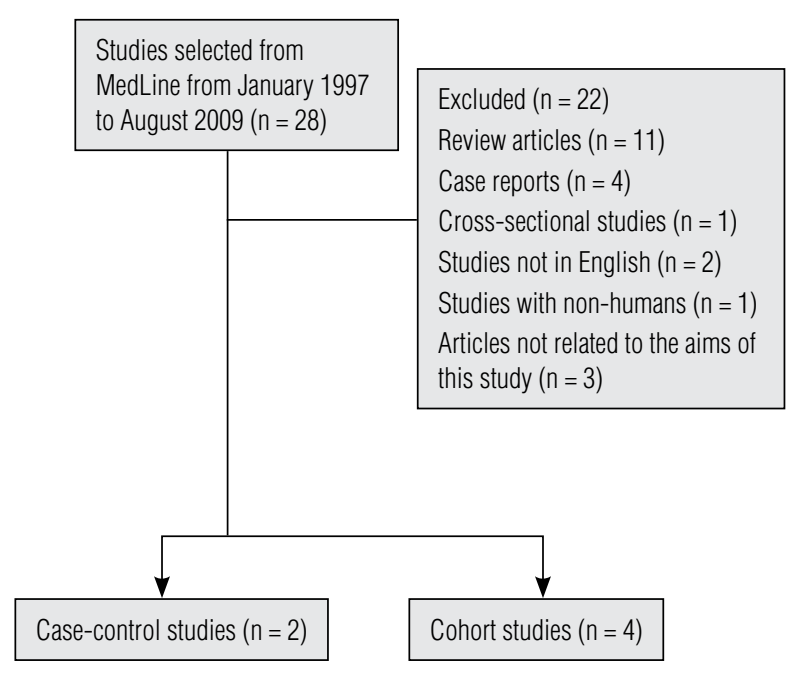

Figure 1. Strategy for searching the literature.

\section{RESULTS}

Six studies were included, comprising four cohort and two case-control studies. Three of these studies evaluated bone metabolism and BMD, while the other evaluated bone metabolism only. The surgical technique employed in five of the studies was the Roux-en-Y gastric bypass (Capella Gastroplasty) and the other was performed using biliodigestive derivation (Scopinaro surgery).

Moreiro and cols. (14) evaluated the occurrence of secondary hyperparathyroidism (SHPT), the relationship between serum PTH and BMI and the effect of biliopancreatic diversion surgery (BPD) on serum PTH, urinary deoxypyridinoline (DPD)/creatinine ratio and serum CTX in 96 morbid obese patients. The patients' ages ranged from 19 to 60 years, $(23$ men and 73 women) with an initial mean BMI of $53 \mathrm{~kg} / \mathrm{m}^{2}$, who were compared with 77 non-obese controls (67 women and 10 men). PTH, DPD and CTX levels were evaluated before surgery and postoperatively at three, six, 12, 18 and 24 months. PTH levels increased gradually six months after surgery with a statistically significant difference when compared to preoperative levels. Despite 
calcium (1,200 mg/day) and vitamin D (800 UI/day) supplements, $77 \%$ of the patients with SHPT before surgery still had high PTH levels two years later and $58 \%$ with normal PTH levels before the BDP developed SHPT. DPD was significantly higher in the cases than in the controls in both sexes, although the basal CTX did not present any significant difference. Serum CTX in women was significantly increased in all evaluations as compared to the basal levels and a significant increase in DPD was demonstrated in both sexes. No correlation was seen between DPD/creatinine and CTX, PTH and urinary calcium or PTH and BMI. Calcium and vitamin D supplementation did not prevent the appearance of SHPT. After BPD, patients with high pre-operative PTH levels presented a higher risk of poor calcium and vitamin $\mathrm{D}$ absorption and an increase in bone resorption, with high DPD and CTX levels.

A prospective study of 193 women (mean age 43.7 $+/-9.2$ and mean BMI $\left.50.8+/-9.6 \mathrm{~kg} / \mathrm{m}^{2}\right)$, conducted by Yousseff and cols. (15) evaluated the effects of the Roux-en-Y gastric bypass surgery (RYGB) on calcium and vitamin D metabolism during the first two years following surgery. High serum PTH $(>65 \mathrm{pg} / \mathrm{mL}$ ) was found in $53.3 \%$, vitamin D deficiency $(<20 \mathrm{ng} / \mathrm{mL})$ in $20.2 \%$ and hypocalcemia in $2 \%$ of patients. All patients received calcium citrate $(1,200 \mathrm{mg} /$ day $)$ and vitamin D (400 UI/day) after surgery. African-Americans had a 2.5-fold higher risk of developing SHPT than Caucasians and those over 45 years of age had a 1.8-fold higher risk. Patients with high PTH levels had a greater incidence of high levels of serum alkaline phosphatase levels.

Diniz and cols. (16) conducted a prospective study to evaluate the impact of bariatric surgery on serum calcium, phosphorus, magnesium, alkaline phosphatase and PTH in patients submitted to RYBG. Of the 110 class III obese patients, 32 (29\%) had SHPT (PTH > 60 $\mathrm{pg} / \mathrm{dL}$ ), of whom $87.5 \%$ were women, and were evaluated every three months during the first year and, thereafter, every six months. The mean age was 40 years and the mean time for post-operative increased PTH level was 41.5 months (range, 3-80 months). No differences were seen in serum PTH levels when the early postoperative period was compared to the late. Hypocalcemia was observed in only one $(0.9 \%)$ individual in the total sample, and $3.1 \%$ of those with high PTH levels. Thirteen $(40.6 \%)$ individuals presented levels between 60 and $80 \mathrm{pg} / \mathrm{dL}, 12(38 \%)$ between 81 and $100 \mathrm{pg} / \mathrm{mL}$, and seven $(22 \%)$ had levels above $101 \mathrm{pg} / \mathrm{dL}$.
A longitudinal, prospective study conducted by Carrasco and cols. (2) set out to evaluate the effects of food intake, micronutrient supplementation, body composition and serum levels of adiponectin in BMD reduction after bariatric surgery. Forty-two obese women with a mean age of $37.7 \pm 9.6$ years, and a mean BMI of $45.0 \pm 4.3 \mathrm{~kg} / \mathrm{m}^{2}$, were observed before RYBG surgery and postoperatively at six and 12 months. All patients took calcium $(640-1,000 \mathrm{mg})$ and vitamin D (400-800 U) throughout the observation period. There was a significant reduction in BMD at the lumbar spine $(-7.4 \% \pm 6.8 \%)$ and total femur $(-10.5 \% \pm 5.6 \%)$ after 12 months. Despite the statistically significant bone loss, only four patients had levels corresponding to low bone mass in the total femur and none showed a level corresponding to low bone mass and osteoporosis in the spine. Serum levels of adiponectin had increased by $48 \%$ in the sixth month and $97 \%$ in the $12^{\text {th }}$. Bone loss had a positive correlation with initial weight, initial fat mass, percentage of weight loss, adiponectin levels in the $12^{\text {th }}$ month post-RYBG, and with the variation of adiponectin levels during the observation period.

Pereira and cols. (17) evaluated 39 women - 11 non-obese, 12 obese and 16 obese submitted to RYBG - with the aim of determining BMD and the biochemical parameters of bone remodeling at three years after undergoing RYBG. The obese group submitted to RYBG received a daily supplementation of $400 \mathrm{U}$ of vitamin D and $250 \mathrm{mg}$ of calcium carbonate. In an initial cross-sectional analysis, there were no significant differences in the serum levels of calcium, alkaline phosphatase, albumin, magnesium, PTH and 25OHD. Urinary calcium and serum IGF-1 levels were significantly lower in the group of obese individuals submitted to surgery in relation to the two other groups. Serum osteocalcin was lower in the two groups of obese patients than in the control group. With regard to BMD, significantly higher values were found in Ll-L4 in the obese groups submitted to RYBG $\left(1.104 \pm 0.03 \mathrm{~g} / \mathrm{cm}^{2}\right)$ in relation to the control group $\left(0.955 \pm 0.03 \mathrm{~g} / \mathrm{cm}^{2}\right)$, with no significant differences in the femoral neck between these groups $\left(0.821 \pm 0.04 v s .0 .8865 \pm 0.02 \mathrm{~g} / \mathrm{cm}^{2}\right.$, respectively). In the distal radius, similar data were found in the non-obese and the non-operated obese groups and significantly higher values in the group submitted to RYBG in relation to the other two groups. Following the cross-sectional analysis, eight patients were selected from each group and observed during a period of one year. In the longitudinal prospective study, BMD re- 
mained stable in the non-obese and obese groups not submitted to RYBG. In the individuals submitted to RYBG a significant reduction in BMD was found at all sites analyzed. Serum PTH and 25OHD levels remained stable in all three groups, and urinary DPD was significantly higher in the group submitted to RYBG than in the other two groups.

Fleischer and cols. (18) in a one-year prospective study with 23 men and women with morbid obesity evaluated the alterations in mineral metabolism and BMD after RYBG. Measurements of serum calcium, $25(\mathrm{OH}) \mathrm{D}$, 1.25-dihydroxyvitamin $\mathrm{D}$, osteocalcin, $\mathrm{PTH}, 24$-hour urinary calcium and $\mathrm{N}$-telopeptides (NTx) were made before surgery and postoperatively at three, six and twelve months. BMD was evaluated at the femoral neck, the total femur, the lumbar spine and the distal radius pre-operatively and one year after surgery. Mean BMI was $47 \pm \mathrm{l} \mathrm{kg} / \mathrm{m}^{2}$, ages ranged from 20 to 64 years, and $78 \%$ were women of whom $59 \%$ were premenopausal. The mean daily intake of calcium and vitamin $\mathrm{D}$ through diet and supplementation was $1,318 \pm 145 \mathrm{mg}$ (range, 388-2587) and $658 \pm 117 \mathrm{UI}$ (range, 0-2045), respectively. Despite the relatively high intake of vitamin $\mathrm{D}$, the majority of individuals presented serum $25(\mathrm{OH}) \mathrm{D}$ below the desired levels with $87 \%$ showing levels less than $30 \mathrm{ng} / \mathrm{mL}$ and $43 \%$ levels less than $20 \mathrm{ng} / \mathrm{mL}$. Mean concentration of PTH was 43 $\pm 4 \mathrm{pg} / \mathrm{mL}$. Serum calcium, 1.25-dihydroxyvitamin D, osteocalcin and urinary calcium and NTx were normal. Mean weight loss was $45 \pm 2 \mathrm{~kg}(\mathrm{p}<0.01)$ and mean BMI fell from $47 \pm 1$ to $31 \pm 1 \mathrm{~kg} / \mathrm{m}^{2}(\mathrm{p}<0.001)$ over 12 months. The daily intake of calcium almost doubled during the first three months $(1,318-2,488 \mathrm{mg} /$ day; $\mathrm{p}<0.01)$ and remained significantly high at six months $(\mathrm{p}<0.01)$ and 12 months $(\mathrm{p}<0.01)$. Vitamin D intake increased significantly from the basal evaluation to six months $(658 \pm 117 \mathrm{UI} /$ day to $1195 \pm 188 \mathrm{UI} /$ day; $\mathrm{p}$ $<0.05)$ and a 2.5 increase was seen at 12 months $(658$ $\pm 117 \mathrm{UI} /$ day to $1698 \pm 354 \mathrm{UI} /$ day; $\mathrm{p}<0.05)$. In spite of this, serum levels of $25(\mathrm{OH}) \mathrm{D}$ did not increase at any time of the evaluation period and the majority of individuals remained below the desirable levels at 12 months. Although the daily intake of calcium increased after three months, there was a reduction in the 24hour urinary calcium from 112 to $77 \mathrm{mg} / \mathrm{g}$ of creatinine $(\mathrm{p}<0.01)$ and a simultaneous increase in PTH $(\mathrm{p}$ $<0.01$ ) was observed. Serum 1.25-dihydroxyvitamin $\mathrm{D}$ did not show any significant post-operative changes. One year after surgery there was significant reduction in BMD in the femoral neck $(-9,2 \%$; $<<0.005)$ an the decrease in BMD was strongly associated with the extent of weight loss, mainly in the femoral neck and also associated with higher PTH levels. Bone turnover markers began to increase after three months and continued to do so progressively during the first year. There was strong evidence of early bone resorption after surgery, with increased levels of urinary NTx of $57 \%$ at three months $(\mathrm{p}<0.01), 86 \%$ at six months $(\mathrm{p}<$ $0.01)$ and $106 \%$ at 12 months $(\mathrm{p}<0.01)$. There was also a significant increase in serum osteocalcin of $39 \%$ at 12 months $(\mathrm{p}<0.01)$.

\section{DISCUSSION}

Although some studies have demonstrated a significant effect of bariatric surgery on bone metabolism especially in relation to the development of SHPT and the bone loss, data are still limited. Also, certain questions, such as the real effects of these alterations on the risk of fracture and the ideal supplementation doses of calcium and vitamin D3 after surgery, remain unanswered. Similarly, there is still certain controversy regarding a number of pathophysiological aspects associated with the osteometabolic alterations in the patient after bariatric surgery.

It is well established that SHPT is related to a combination of lower calcium dietary intake and a decreased absorption of the mineral following malabsorption surgery (19). The prevalence of hyperparathyroidism may reach $58 \%$ in patients after RYBG $(14-15,18)$. Furthermore, patients submitted to bariatric surgery may present chronic magnesium depletions which also leads to a blunt in PTH secretion, osteoporosis and vitamin D deficiency (20).

In spite of their low absorption levels of calcium, hypocalcemia is not commonly found in these patients, probably because of the compensatory action of SHPT. The prevalence found in the studies analyzed ranged from $0.9 \%$ to $2 \%$ (15-16), and may therefore be a low sensitivity marker for evaluating bone disease in this population, as with alkaline phosphatase, for which Diniz and cols. (16) demonstrated an increase of only $1.8 \%$ in patients submitted to RYBG.

The 24-hour urinary calcium presents a significant reduction in operated patients (17-18) even with adequate calcium replacement, which may be associated with a reduced intestinal absorption and, concomitantly, an increased need for a higher daily intake of calcium.

A reduction in calcium absorption and SHPT may also be related to insufficient levels of $25(\mathrm{OH}) \mathrm{D}$. For many years, obesity has been related to vitamin $\mathrm{D}$ deficiency, osteomalacia and SHPT. Many studies have negatively associated obesity with the status of serum 
25(OH)D (21-25) including data that estimate a suboptimal status of this steroid in $80 \%$ of obese individuals (26). Because of this association, it has been proposed that obesity leads to an increase in the clearance of $25(\mathrm{OH}) \mathrm{D}$ as well as a greater capacity to store the vitamin in excess fatty tissue (27), as demonstrated by animal studies and human autopsies (28-29). Other causes, such as less exposure to sunlight and lower production of $25(\mathrm{OH}) \mathrm{D}$ in the liver as a result of steatosis have also been suggested (30).

Interestingly, there is no significant improvement in $25(\mathrm{OH}) \mathrm{D}$ status after bariatric surgery, as reported by a number of authors (31-32). Also, although some studies have mentioned a significant increase in $25(\mathrm{OH}) \mathrm{D}$, levels have remained at suboptimum values, which may contribute to maintaining a state of SHPT (33). Vitamin D deficient people need supplementation of 2000 UI per day; however, patients after bariatric surgery need more than that for efficient restoration.

With regard to the bone loss described in obese patients after surgical procedures, one hypothesis currently being considered is the lower peripheral aromatization of androgens in estrogen that is said to occur with the loss of fatty tissue. However, the pathogenesis of bone loss after gastroplasty seems to be different from that involved in low estrogen status, as demonstrated by experimental studies in animals (34-35). While estrogen deficiency, whether related to the post-menopausal period or other secondary causes, leads to an increase in bone resorption predominantly trabecular, the bone loss related to bariatric surgery produces an increase in bone resorption in both the cortical and trabecular sites (3435). It may be stated, however, that in this latter case, the negative balance of calcium generated by the loss of normal absorptive physiology of the gastrointestinal tract may be the fundamental mechanism for the occurrence of bone loss. Fleischer and cols. (18) reported that the extension of weight loss is directly associated with the intensity of the reduction in BMD at all sites.

Other possible factors involving hormone production by fatty tissue may also be related to the pathophysiology of the increased bone resorption in these patients. Leptin is a hormone with a central anorexigen action produced by the adipocytes that presents with high levels in obesity and seems to be related to peripheral resistance to its action (36). Recently, an anti-estrogen effect of leptin was described through the activation of the sympathetic nervous system, which, on activating the adrenergic beta- 2 receptors present in the osteoblast membrane, leads to the differentiation of the osteoclasts through the RANK-RANKL system (36). As weight loss following bariatric surgery leads to a decrease in leptin resistance the antiosteogenic effect of this hormone is facilitated.

Another hormone also produced by the adipocytes and that may be involved with this pathogenesis, is adiponectin, which tends to present lower levels in obese patients. Also mediated through the RANK-RANKL system, this hormone stimulates bone resorption with levels being inversely correlated with bone mass (37-38). It is well known that postoperative weight loss causes an increase in adiponectin production, and therefore contributes to greater bone loss in these individuals. Carrasco and cols. (2) demonstrated that adiponectin presents a positive correlation with weight loss and a reduction in BMD six and 12 months after RYBG, leading to the hypothesis that it may be a marker for bone remodeling in patients submitted to RYBG. However, there is a need for more studies to corroborate these findings.

Bone resorption occurs very soon after surgery with increased levels of urinary NTx (18), CTX (14) and DPD $(14,17)$ at three months and serum osteocalcin at 12 months (18). It is worth mentioning, however, that according to some studies the bone mass of obese patients, even after loss following surgery, still remains greater than in non-obese individuals (39). However, the real clinical consequences of bariatric surgery on bone metabolism remain unclear. A recent study from Mayo Clinic, presented at The $91^{\text {st }}$ Annual Meeting of the Endocrine Society reported an increase in fracture risk in patients who had undergone bariatric surgery in comparison to what would be expected for people from the general population at the same age (40).

On the basis of this review, bariatric surgery is associated with changes in bone metabolism, bone loss and a possible increased risk of fracture. However, the maximum evaluation period covered by the studies in question was two years after surgery, thus suggesting a need to undertake further studies of longer duration in order to achieve a more thorough understanding of this association.

Disclosure: no potential conflict of interest relevant to this article was reported.

\section{REFERENCES}

1. WHO [Internet]. Geneva: Global Database on Body Mass Index: an interactive surveillance tool for monitoring nutrition transition; c1997 [Update 2009 Oct 10]. Available from: http://apps.who. int/bmi/index.jsp?introPage=intro_4_3.html. 
2. Carrasco F, Ruz M, Rojas P, Csendes A, Rebolledo A, Codoceo J, et al. Changes in bone mineral density, body composition and adiponectin levels in morbidly obese patients after bariatric surgery. Obes Surg. 2009;19(1):41-6.

3. Bell NH, Epstein S, Greene A, Shary J, Oexmann MJ, Shaw S. Evidence for alteration of the vitamin D-endocrine system in obese subjects. J Clin Invest. 1985;76(1):370-3.

4. LielY, Ulmer E, Shary J, Hollis BW, Bell NH. Low circulating vitamin D in obesity. CalcifTissue Int. 1988;43(4):199-201.

5. Wortsman J, Matsuoka LY, Chen TC, Lu Z, Holick MF. Decreased bioavailability of vitamin $\mathrm{D}$ in obesity. Am $\mathrm{J}$ Clin Nutr. 2000;72(3):690-3.

6. Compston JE, Vedi S, Ledger JE, Webb A, Gazet JC, PilkingtonTR. Vitamin $\mathrm{D}$ status and bone histomorphometry in gross obesity. Am J Clin Nutr. 1981;34(11):2359-63.

7. Hyppönen E, Power C. Hypovitaminosis D in British adults at age $45 \mathrm{y}$ : nationwide cohort study of dietary and lifestyle predictors. Am J Clin Nutr. 2007;85(3):860-8.

8. Flancbaum L, Belsley S, Drake V, Colarusso T, Tayler E. Preoperative nutritional status of patients undergoing Roux-en- $Y$ gastric bypass for morbid obesity. J Gastrointest Surg. 2006;10(7):1033-7.

9. Carlin AM, Rao DS, Meslemani AM, Genaw JA, Parikh NJ, Levy $S$, et al. Prevalence of vitamin D depletion among morbidly obese patients seeking gastric bypass surgery. Surg Obes Relat Dis. 2006;2(2):98-103.

10. Stein EM, Strain G, Sinha N, Ortiz D, Pomp A, Dakin G, et al. Vitamin $D$ insufficiency prior to bariatric surgery: risk factors and a pilot treatment study. Clin Endocrinol. 2009;71(2):176-83.

11. Viégas MA, Bandeira L, Bandeira F. Complicações metabólicas da cirurgia bariátrica. In: Bandeira F, Graf H, Griz L, Faria M, LazarettiCastro M, editors. Endocrinologia e Diabetes. 2th ed. Rio de Janeiro: Medbook; 2009. p. 1038-45.

12. Shaker JL, Norton AJ, Woods MF, Fallon MD, Findling JW. Secondary hyperparathyroidism and osteopenia in women following gastric exclusion surgery for obesity. Osteoporos Int. 1991;1(3):177-81.

13. Ricci TA, Heymsfield SB, Pierson RN Jr, StahlT, Chowdhury HA, Shapses SA. Moderate energy restriction increases bone resorption in obese postmenopausal women. Am J Clin Nutr. 200;73(2):347-52.

14. Moreiro J, Ruiz O, Perez G, Salinas R, Urgeles JR, Riesco M, et al. Parathyroid hormone and bone marker levels in patients with morbid obesity before and after biliopancreatic diversion. Obes Surg. 2007;17(3):348-54.

15. Youssef Y, Richards WO, Sekhar N, Kaiser J, Spagnoli A, Abumrad N, et al. Risk of secondary hyperparathyroidism after laparoscopic gastric bypass surgery in obese women. Surg Endosc. 2007;21(8):1393-6.

16. Diniz MF, Diniz MT, Sanches $S R$, Salgado PP, Valadão MM, Araújo FC, et al. Elevated serum parathormone after Roux-en-Y gastric bypass. Obes Surg. 2004;14(9):1222-6.

17. Pereira FA, de Castro JA, dos Santos JE, Foss MC, Paula FJ. Impact of marked weight loss induced by bariatric surgery on bone mineral density and remodeling. Braz $\mathrm{J}$ Med Biol Res. 2007;40(4):509-17.

18. Fleischer J, Stein EM, Bessler M, Della Badia M, Restuccia N, Olivero-Rivera $L$, et al. The decline in hip bone density after gastric bypass surgery is associated with extent of weight loss. $\mathrm{J}$ Clin Endocrinol Metab. 2008;93(10):3735-40.

19. Schweitzer DH. Mineral metabolism and bone disease after bariatric surgery and ways to optimize bone health. Obes Surg. 2007;17(11):1510-6.

20. Sahota O, Mundey MK, San P, Godber IM, Hosking DJ. Vitamin D insufficiency and the blunted PTH response in established osteoporosis: the role of magnesium deficiency. Osteoporos Int. 2006;17(7):1013-21.
21. Arunabh S, Pollack S, Yet J, Aloia JF. Body fat content and 25-hydroxyvitamin D levels in healthy women. J Clin Endocrinol Metab. 2003;88(1):157-61.

22. Kamycheva E, Sundsfjord J, Jorde R. Serum parathyroid hormone level is associated with body mass index. The 5th Tromso Study. Eur J Endocrinol. 2004;151(2):167-72.

23. Parikh SJ, Edelman M, Uwaifo GI, Freedman RJ, Semega-Janneh M, Reynolds $\mathrm{J}$, et al. The relationship between obesity and serum 1,25-dihydroxy vitamin D concentrations in healthy adults. J Clin Endocrinol Metab. 2004;89(3):1196-9.

24. Yanoff LB, Parikh SJ, Spitalnik A, Denkinger B, Sebring NG, Slaughter $P$, et al. The prevalence of hypovitaminosis $D$ and secondary hyperparathyroidism in obese Black Americans. Clin Endocrinol. 2006;64(5):523-9.

25. Snijder MB, van Dam RM, Visser M, Deeg DJ, Dekker JM, Bouter $\mathrm{LM}$, et al. Adiposity in relation to vitamin $\mathrm{D}$ status and parathyroid hormone levels: a population-based study in older men and women. J Clin Endocrinol Metab. 2005;90(7):4119-23.

26. Bischof MG, Heinze G, Vierhapper H. Vitamin D status and its relation to age and body mass index. Horm Res. 2006;66(5):211-5.

27. Wortsman J, Matsuoka LY, Chen TC, Lu Z, Holick MF. Decreased bioavailability of vitamin $\mathrm{D}$ in obesity. Am J Clin Nutr. 2000;72(3):690-3.

28. Brouwer DA, van Beek J, Ferwerda $H$, Brugman AM, van der Klis $\mathrm{FR}$, van der Heiden $\mathrm{HJ}$, et al. Rat adipose tissue rapidly accumulates and slowly releases an orally-administered high vitamin D dose. Br J Nutr. 1998;79(6):527-32.

29. Mawer EB, Backhouse J, Holman CA, Lumb GA, Stanbury SW. The distribution and storage of vitamin $D$ and its metabolites in human tissues. Clin Sci. 1972;43(3):413-31.

30. Bell NH, Epstein S, Greene A, Bhary J, Oexmann MJ, Shaw S. Evidence for alteration of the vitamin $D$-endocrine system in obese subjects. J Clin Invest. 1985;76(1):370-3.

31. El-Kadre LJ, Rocha PRS, Tinoco AC, Tinoco RC. Calcium metabolism in pre- and post-menopausal morbidly obese women at baseline and after laparoscopic Roux-en-Y gastric bypass. Obes Surg. 2004;14(8):1062-6.

32. Johnson JM, Maher JW, DeMaria EJ, Downs RW, Wolfe LG, Kellum KM. The long-term effects of gastric bypass on vitamin D metabolism. Ann Surg. 2006;243(5):701-4.

33. Carlin AM, Rao DS, Yager KM, Genaw JA, Parikh NJ, SzymanskiW. Effect of gastric bypass surgery on vitamin D nutritional status. Surg Obes Relat Dis. 2006;2(6):638-42.

34. Klinge B, Lehto-Axtelius D, Akerman M, Hakanson R. Structure of calvaria after gastrectomy. An experimental study in the rat. Scand J Gastroenterol. 1995;30(10):952-7.

35. Surve VV, Andersson N, Lehto-Axtelius D, Håkanson R, Surve VV, Andersson N, et al. Comparison of osteopenia after gastrectomy, ovariectomy and prednisolone treatment in the young female rat. Orthop Scand. 2001;72(5):525-32.

36. Karsenty G. Convergence between bone and energy homeostases: leptin regulation of bone mass. Cell Metab. 2006;4(5):341-8.

37. Lenchik L, Register TC, Hsu FC, Lohman K, Nicklas BJ, Freedman $\mathrm{Bl}$, et al. Adiponectin as a novel determinant of bone mineral density and visceral fat. Bone. 2003;33(4):646-51.

38. Luo XH, Guo LJ, Xie H, Yuan LQ, Wu XP, Zhou HD, et al. Adiponectin stimulates RANKL and inhibits OPG expression in human osteoblasts through the MAPK signaling pathway. J Bone Miner Res. 2006;21(10):1648-56.

39. Cundy T, Evans MC, Kay RG, Dowman M, Wattie D, Reid IR. Effects of vertical-banded gastroplasty on bone and mineral metabolism in obese patients. Br J Surg. 1996;83(10):1468-72.

40. Haglind EGC, Kennel KA, Collazo-Clavell ML, Achenbach SJ, Atkinson EJ, Melton JL, et al. Fracture risk after bariatric surgery. 91st Annual Meeting of the Endocrine Society. Washington, DC, 2009.OR07-4. 